\title{
MANAJEMEN TATA RUANG PERPUSTAKAAN PESANTREN MADANI ALAUDDIN PAO-PAO MAKASSAR
}

\author{
Oleh : Muhammad Azwar \& Agung Nugraha Rusli
}

\begin{abstract}
This paper discusses the library building design at school library Madani Alauddin Pao-pao. The library building design is one of the aspect of library development that has the prominent role in carrying out and successing the library functions. A good library design has significant impact to increase users' interest to visit and use the library services due to the the comfort of the study environment. The purpose of the research is to examine the library building design of Pesantren Madani Alauddin Pao-pao and to know whether the school library of Pesantren Madani Pao-pao has fulfilled the National standard of school library (SNP 009:2011).
\end{abstract}

Keywords : library building design, library building management, pesantren library

Abstrak

Tulisan ini membahas tentang manajemen tata ruang perpustakaan Pesantren Madani Alauddin Paopao. Tata ruang merupakan salah satu aspek pembinaan perpustakaan yang memiliki pengaruh dan peranan yang sangat besar dalam memperlancar layanan maupun pelaksanaan fungsi perpustakaan. Tata ruang yang baik membuat para pengunjung merasa nyaman berada di perpustakaan yang diharapkan dapat meningkatkan minat pengguna untuk mengunjungi dan memanfaatkan layanan perpustakaan. Tujuan dalam penelitan ini adalah untuk mengetahui manajemen tata ruang Pesantren Madani Alauddin Pao-pao dan untuk mengetahui apakah perpustakaan Pesantren Madani Alauddin Pao-pao sudah memenuhi Standar Nasional Perpustakaan Sekolah (SNP 009:2011).

Kata Kunci : manajemen tata ruang, pesantren madani, standar nasional perpustakaan sekolah

\section{A. PENDAHULUAN}

Perpustakaan sebagai pusat informasi memilikitugas dan fungsi yang harus dijalankan setiap saat, seperti kegiatan administrasi, menyediakan informasi dan memberikan layanan yang optimal. Eksistensinya sebagai suatu tempat untuk memperoleh informasi dianggap sangat urgen demi terciptanya sumber daya manusia yang berkualitas.

Perpustakaan sekolah menurut Standar Nasional Indonesia adalah perpustakaan yang berada pada satuan pendidikan formal di lingkungan pendidikan dasar dan menengah yang merupakan bagian integral dari kegiatan sekolah yang bersangkutan, serta merupakan pusat sumber belajar untuk mendukung tercapainya tujuan pendidikan sekolah yang bersangkutan.

Perpustakaan sekolah merupakan salah satu sarana dalam mengembangkan pengetahuan, keterampilan, dan sikap para murid. Dalam penyelenggaraannya, perpustakaan memerlukan ruang tersendiri beserta berbagai pelengkapannya. Semakin lengkap perlengkapannya semakin menunjang penyelenggaraan perpustakaan sekolah tersebut. Ruang dan perlengkapan yang tersedia harus ditata dan dirawat dengan baik sehingga dapat menunjang penyelenggaraan perpustakaan sekolah secara efektif dan efisien (Bafadal, 2008:150). 
Tata ruang merupakan salah satu aspek pembinaan perpustakaan yang memiliki pengaruh dan perananyang sangatbesardalam memperlancar layanan maupun pelaksanaan fungsi perpustakaan. Tata ruang yang baik membuat para pengunjung merasa nyaman berada di perpustakaan yang diharapkan dapat meningkatkan minat pemustaka untuk mengunjungi dan memanfaatkan layanan perpustakaan (Prastowo, 2012: 304).

Pesantren Madani Alauddin Pao-pao didirikan oleh Yayasan Keluarga Besar UIN Alauddin Makassar. Pesantren ini merupakan Laboratory School Fakultas Tarbiyah dan Keguruan UIN Alauddin Makassar dan memiliki perpustakaan yang berada di sekitar lokasi pesantren tepatnya di samping ruangan guru. Perpustakaan Pesantren Madani Alauddin Pao-pao sudah menerapkan sistem otomasi perpustakaan dan ruangannya sudah dilengkapi dengan fasilitas, seperti komputer dan AC. Namun, perpustakaan masih kurang memperhatikan aspek keindahan penataan ruangan.

Perpustakaan terlihat kurang terawat dan kurang tertata dengan baik, mungkin dikarenakan penanggung jawab perpustakaan bukan seorang pustakawan yang berlatar belakang pendidikan Ilmu Perpustakaan, melainkan seorang guru dengan jadwal mengajar yang cukup padat sehingga tidak memiliki waktu luang untuk mengurus perpustakaan Pesantren Madani Alauddin Pao-pao.

Tata ruang perpustakaan Pesantren Madani Alauddin Pao-pao juga terlihat kurang menarik dan kurang nyaman. Hal ini dikarenakan tidak adanya fasilitas meja baca, kurangnya jumlah rak, dan banyaknya tumpukan kardus berisi buku di sekitar rak yang mengganggu kenyamanan pemustaka, sehingga tata ruang perpustakaan Pesantren Madani Alauddin Paopao belum sesuai dengan Standar Nasional Perpustakaan (SNP). Masalah lainnya, pesantren tidak memiliki banyak ruangan sehingga perpustakaan dan laboratorium komputer digabung menjadi satu ruangan dan hanya dibatasi oleh rak buku. Hal ini yang membuat pemustaka kurang nyaman berada di dalamnya.

Berdasarkan uraian di atas, salah satu cara agar perpustakaan tetap berada pada fungsi dan tujuannya, maka perpustakaan Pesantren Madani Alauddin Pao-Pao perlu menerapkan manajemen tata ruang. Hal ini pula yang membuat penulis tertarik untuk membahas dan meneliti lebih jauh mengenai tata ruang Perpustakaan Pesantren Madani Alauddin Pao-Pao.

\section{B. TINJAUAN TEORITIS}

\section{Manajemen Perpustakaan}

a. Pengertian Manajemen

Secara etimologis kata manajemen berasal dari bahasa perancis kuno management, yang berarti seni melaksanakan dan mengatur. Sedangkan secara terminologis para pakar mendefinisikan manajemen secara beragam di antaranya :

Manajemen sebagai pengetahuan tentang proses penggunaan dan pengelolaan sumber daya, manusia, modal, dan peralatan lainnya secara terpadu dan efektif untuk mencapai sasaran yang diharapkan (Kamus Besar Bahasa Indonesia, 2013 : 559).

Manajemen sebagai pencapaian sasaran-sasaran organisasi dengan cara yang efektif dan efisien melalui perencanaan, pengorganisasian, kepemimpinan, dan pengendalian sumber daya organisasi (draft, $2002: 8$ )

Manajemen sebagai suatu ilmu juga seni untuk membuat orang lain mau dan bersedia berkerja untuk mencapai tujuan yang telah dirumuskan bersama oleh sebab itu manajemen memerlukan konsep dasar pengetahuan, kemampuan untuk menganalisis situasi, kondisi, sumber daya manusia yang ada dan memikirkan cara yang tepat untuk melaksanakan kegiatan yang saling berkaitan untuk mencapai tujuan (Ahmad , 2002: 4)

Manajemen sebagai proses melaksanakan dan mengatur sehingga dipandang sebagai cara untuk memanfaatkan semua sumber daya yang ada untuk mencapai tujuan yang 
telah ditentukan (Mathar, 2012 : 17)

Manajemen adalah suatu proses di mana kita harus mengatur memanfaatkan sumber daya yang ada untuk mencapai tujuan.

Manajemen Perpustakaan dapat diartikan sebagai upaya sebuah organisasi perpustakaan untuk mencapai tujuan yang tertuang di dalam visi dan misi organisasi melalui sebuah proses yang dilakukan secara bersama atau berkelompok.

\section{b. Kegiatan Manajemen}

Henri Fayol mengemukakan bahwa perpustakaan sebaiknya melakukan kegiatan sebagai berikut :

\section{1) Planning (perencanaan)}

Perencanaan merupakan langkah awal dalam merumuskan segala hal. Layanan perpustakaan akan sangat efektifdam efisienjika dimulai dengan kegiatan perencanaan, khususnya yang berhubungan dengan analisis kebutuhan pemustaka.

2) Organizing (pengorganisasian)

Pengorganisasian perpustakaan dilakukan setelah melakukan analisis terhadap sumber daya yang dimiliki oleh perpustakaan itu sendiri.

3) Commanding (pengkomandoan)

Pengkomandoan sangat identik dengan kecakapan seorang pimpinan atau manajer. Seorang pemimpin perpustakaan sebaiknya memahami konsep-konsep manajerial yang baik agar dia mampu memahami karakter dan kemampuan staf dan pustakawan lingkup kerja organisasinya.

4) Coordinating (pengkoordinasian) Kordinasi antar bagian dalam sebuah organisasi sangat ditentukan oleh struktur organisasi. Kapabilitas sebuah organisasi dapat diukur secara kasat mata melalui struktur organisasinya.

5) Controlling (pengkontrolan)

Kontrol terhadap kinerja organisasi dapat dilakukan secara internal maupun eksternal dengan cara melibatkan pihak luar untuk menjadi pengontrol independen (Mathar, $2012: 6)$.

\section{Tata Ruang Perpustakaan}

a. Pengertian Tata Ruang Perpustakaan

Penataan ruangan perpustakaan perlu dilakukan secara hati-hati dan mempertimbangkan berbagai aspek. Untuk dapat memikat perhatian pemustaka agar mau datang ke perpustakaan, salah satu cara yang bisa dilakukan adalah melalui penataan ruangan yang menarik dan fungsional (Suwarno, 2011: 45).

Ruangan yang tertata rapi dan bukubuku yang juga tertata akan membuat suatu perpustakaan memberikan nuansa nyaman sehingga pemustaka tertarik untuk membaca buku dan betah berada di perpustakaan (Anugrah, 2013).

Tata ruang adalah penataan atau penyusunan segala fasilitas di ruang atau gedung yang tersedia (Bafadal, 2009: 163).

Tata ruang adalah pengaturan dan penyusunan seluruh mesin kantor, alat perlengkapan kantor, serta perabot kantor pada tempat yang tepat sehingga pegawai dapat bekerja dengan baik, nyaman leluasa dan bebas bergerak, sehingga tercapai efisiensi kerja (Sedarmayanti , 2001: 125).

Tata ruang perpustakaan adalah salah satu cara untuk menciptakan suasana kondusif dan menyenangkan dalam perpustakaan dengan upaya penyusunan perabot dan perlengkapan perpustakaan pada tata letak dan susunan yang tepat serta pengaturan tempat kerja sehingga memberi kepuasan kerja para pustakawan dan pengguna perpustakaan secara efisien dan efektif disebuah perpustakaan.

b. Tujuan, Asas-asas, dan Sistem Tata Ruang Perpustakaan

Pengaturan tata ruang yang menarik dan fungsional akan 
mengakibatkan pelaksanaan tugas dan fungsi perpustakaan dapat diatur secara tertib dan lancar. Dengan demikian komunikasi baik antar petugas perpustakaan (pustakawan) maupun pengguna perpustakaan akan semakin lancar, sehingga koordinasi dan pengawasan semakin mudah serta mendapatkan pencapaian efisiensi dan kenyamanan kerja.

Tata atau penataan ruang perpustakaan bertujuan untuk :

1) memperoleh efektivitas kegiatan dan efisiensi waktu, tenaga dan anggaran.

2) menciptakan lingkungan yang aman suara, nyaman cahaya, nyaman udara dan nyaman warna.

3) meningkatkan kualitas pelayanan.

4) meningkatkan kinerja petugas perpustakaan (Lasa HS, 2005: 148).

Di samping tujuan tata ruang perpustakaan yang harus dicapai, perlu juga diperhatikan asas-asas tata ruang, agar penataan dan pemanfaatan ruangan dapat tertata dengan baik. Adapun asasasas tata ruang antara lain:

1) asas jarak; yaitu suatu susunan tata ruang yang memungkinkan proses penyelesaian pekerjaan dengan menempuh jarak yang paling pendek.

2) asas rangkaian karya; yaitu suatu tata ruang yang menempatkan tenaga dan alat dalam suatu rangkaian yang sejalan dengan urutan penyelesaian pekerjaan yang bersangkutan.

3) asas pemanfataan; yaitu tata susunan ruang yang memanfaatkan sepenuhnya ruang yang ada (Lasa HS, 2005: 149).

Untuk kenyamanan pengguna maupun petugas dalam meningkatkan produktifitas, efisiensi, dan efektifitas kerjanya di dalam ruangan perpustakaan, perlu diperhatikan penataan ruang seperti ruang baca, ruang koleksi dan ruang sirkulasi dengan menggunakan beberapa sistem tata ruang perpustakaan yaitu:

1) Sistem tata sekat ; yaitu cara pengaturan ruangan perpustakaan yang menempatkan koleksi terpisah dari ruang baca pengunjung. Dalam sistem ini, pengunjung tidak diperkenankan masuk ke ruang koleksi dan petugaslah yang akan mengambilkan dan mengembalikan koleksi yang dipinjam atau dibaca di tempat itu. Namun demikian sistem ini bisa juga diterapkan pada sistem terbuka,yakni pemustaka mengambil sendiri lalu dicatatkan/dilaporkan kepada petugas, selanjutnya petugaslah yang mengembalikan ke rak semula.

2) Sistem tata parak ; yaitu sistem pengaturan ruangan perpustakaan yang menempatkan koleksi terpisah dari ruang baca. Hanya saja dalam sistem ini, pembaca dimungkinkan untuk mengambil koleksi sendiri, lalu dicatat atau dibaca di ruang lain yang tersedia. Cara ini lebih cocok untuk perpustakaan yang menganut sistem pinjam terbuka.

3) Sistem tata baur ; yaitu suatu cara penempatan koleksi yang dicampur dengan ruang baca agar pembaca lebih mudah mengambil dan mengembalikan sendiri. Sistem ini lebih cocok untuk perpustakaan yang menggunakan sistem pinjam terbuka (Lasa HS, 2005: 158).

\section{c. Ruangan Perpustakaan}

Ruangan perpustakaan adalah salah satu unsur yang paling dominan dari eksistensi atau keberadaan suatu perpustakaan (Prastowo, 2012: 300).

Menurut Yusuf dan Suhendar dalam Prastowo (2012: 301) ruangan perpustakaan yang dimaksud adalah tempat diselenggarakannya perpustakaan. Demikian pentingnya kedudukan ruangan perpustakaan, sehingga banyak ahli yang memberikan batasan perpustakaan sebagai "ruangan" tempat dihimpunnya berbagai macam sumber informasi. Tanpa ruangan, perpustakaan tidak akan dapat menjalankan perpustakaan dengan baik. 
Pada dasarnya suatu perpustakaan yang paling sederhana sekalipun harus memiliki sejumlah ruangan yang mempunyai fungsi yang berlainan. Dengan kata lain, suatu perpustakaan mempunyai ruang pokok, yang merupakan kebutuhan minimal setiap perpustakaan.

Adapun ruangan yang minimal harus dimiliki sebuah perpustakaan adalah sebagai berikut :

1) Ruang koleksi

Ruang koleksi adalah tempat penyimpanan koleksi perpustakaan, luas ruangan ini tergantung pada jenis dan jumlah bahan pustaka yang dimiliki serta besar kecilnya luas bangunan perpustakaan. Ruangan koleksi dapat terdiri dari suatu ruangan atau beberapa ruang, misalnya ruang koleksi buku, ruang koleksi majalah, ruang koleksi referensi, ruang koleksi Audio Visual dan lain-lain.

2) Ruang baca

Ruang baca adalah ruang yang digunakan untuk membaca bahan pustaka. Luas ruangan ini tergantung pada jumlah pembaca/pemakai jasa perpustakaan.

3) Ruang pelayanan

Ruang Pelayanan adalah tempat peminjaman dan pengembalian buku, meminta keterangan kepada petugas, menitipkan barang atau tas, mencari informasi dan buku yang diperlukan melalui katalog.

4) Ruang kerja teknis administrasi

Ruang Kerja Teknis Administrasi adalah ruangan yang dipergunakan untuk melakukan kegiatan-kegiatan, seperti pemerosesan bahan pustaka mulai dari pengadaan sampai bahan pustaka tersebut siap untuk disajikan kepada pemakai perpustakaan, ruang tata usaha untuk kepala perpustakaan dan stafnya, dan ruang untuk memperbaiki bahan pustaka yang rusak.

5) Ruang khusus
Ruang khusus adalah ruang yang terdiri dari kamar kecil, ruang diskusi/pertemuan, ruang bercerita untuk anak-anak dan ruang lain untuk kantin (Departmen Pendidikan Nasional RI, 2004: 5)

Dari sekian jumlah ruangan perpustakaan yang disebutkan di atas, perlu mengadakan pengaturan sedemikian rupa, sehingga memberikan kesan sejuk, menyenangkan, bagi petugas perpustakaan serta dapat mengundang para pemakai menggunakan bahan perpustakaan serta membacanya.

Ruang perpustakaan adalah tempat atau bagian tertentu dalam suatu gedung perpustakaan yang memiliki fungsi tertentu seperti ruang koleksi, ruang untuk pengguna (baca), dan ruang staf pelayanan. Desain interior perpustakaan yang mengintegrasikan nilai-nilai estetika akan berdampak terhadap pemanfaatan jasa perpustakaan oleh pengguna (Fahmi, 2013)

\section{d. Lingkungan dan Kondisi Fisik Tata} Ruang Perpustakaan

Penataan ruang perpustakaan yang serasi, bersih dan tenang dapat mempengaruhi kenyamaan pengguna perpustakaan untuk berlama-lama berada di perpustakaan, serta dapat meningkatkan kinerja petugas perpustakaan. Untuk itu, penataaan ruangan perlu dilakukan secara hatihati dan mempertimbangkan berbagai aspek.

Salah satu cara yang dilakukan pustakawan adalah penataan ruangan yang menarik dan fungsional. Selain itu, perpustakaan harus memperhatikan faktor lingkungan fisik pada tata ruang perpustakaan, karena lingkungan dan kondisi fisik tata ruang yang baik dapat mempengaruhi hasil kinerja seseorang.

Bila kondisi lingkungan kerja baik, seseorang tersebut mampu melakukan kegiatannya secara optimal dengan 
baik, sehat, nyaman, dan tenang.

Menurut Lasa HS (2005: 161) yang termasuk fisik tata ruang perpustakaan adalah:

\section{1) Tata letak}

Di dalam suatu perpustakaan penempatan dan penataan perabot maupun kelengkapan lainnya serta bahan-bahan bacaan perlu diletakkan dan ditata sedemikian rupa agar apa yang disajikan kelihatan menarik minat pemustaka.

Perlu diperhatikan bahwa tata letak perabot dan perlengkapan perpustakaan diupayakan mengalami perubahan dalam jangka waktu tertentu, agar dapat menghilangkan kesan yang membosankan dan menjenuhkan serta memberikan suasana yang lebih segar dan menyenangkan baik bagi pengguna perpustakaan maupun penyelenggara perpustakaan.

\section{2) Ventilasi (ventilasi/suhu ruangan)}

Ventilasi secara sederhana dapat diartikan sebagai perputaran udara secara bebas di dalam suatu ruangan. Demikian halnya perpustakaan adalah suatu bangunan harus mempunyai sistem ventilasi karena ventilasi merupakan salah satu komponen yang terdapat pada kondisi fisik tata ruang perpustakaan, yang dapat membantu perputaran udara dengan lancar yang akan memberikan kenyamanan dan kesegaran udara bagi penyelenggara perpustakaan maupun penggunanya.

Hal-hal yang perlu diperhatikan dalam penempatan ventilasi adalah :

a) menempatkan lubang ventilasi jendela/ lubang angin pada sisi dinding yang berhadapan.

b) mengusahakan agar lubang ventilasi tersebut sejajar dengan arah angin.

c) mengusahakan luas lubang ventilasi sebanding dengan persyaratan dan fasilitas ruang, (sekurang-kurangnya 10\% dari luas ruang yang bersangkutan).

Penentuan letak lubang ventilasi juga perlu diperhatikan agar kondisi ruang mempunyai tingkat kelembaban yang rendah sehingga keamanan dari koleksi buku dan pustaka yang lain dapat terjamin. Terdapat dua macam sistem ventilasi yang digunakan oleh perpustakaan, yaitu ventilasi pasif dan ventilasi aktif.

Ventilasi pasif, ventilasi yang didapatkan dari alam. Caranya dengan membuat lubang angin atau jendela pada sisi dinding yang berhadapan serta sejajar dengan arah angin lokal. Ventilasi aktif adalah ventilasi yang menggunakan sistem penghawaan buatan yaitu menggunakan AC karena temperatur dan kelembaban ruang perpustakaan yang stabil dapat menjaga keawetan koleksi dan peralatan tertentu seperti koleksi langka, pandang dengar dan komputer (Purwanti, 2007: 9).

Kedua jenis ventilasi tersebut mempunyai peran untuk kenyamanan dan keawetan koleksi buku dan bahan pustaka lainnya maupun peralatan (perabot) untuk mencegah gangguan serangga dan cendawan buku. Disamping itu ia juga berperan untuk menjaga kesetabilan temperatur dan kelembaban ruang perpustakaan, sehingga kenyamanan pada ruang perpustakaan tetap terjaga dengan baik, sebab kondisi dalam ruangan akan mempengaruhi kemampuan manusia dalam melaksanakan pekerjaan di ruangan tersebut.

\section{3) Pencahayaan (penerangan)}

Perpustakaan merupakan tempat berbagai jenis kegiatan melihat, dari yang mudah sampai kepada yang sulit, dari membaca huruf besar dengan kontras yang baik antara huruf yang besar dan kertas sampai kepada tulisan tangan dengan pensil yang keras pada kertas kelabu. Dalam pencahayaan ruangan perpustakaan harus cukup terang untuk pengguna supaya bisa 
membaca dan mempelajari buku-buku tertentu agar mata tidak mudah lelah, tata ruang perpustakaan yang baik tidak menimbulkan ruangan menjadi gelap dan terang sekali (Maulani, 2012).

Adapun usaha yang ditempuh agar penerangan tidak menyebabkan penurunan gairah membaca serta tidak membuat silau (Departemen Pendidikan Nasional RI, 2004; 132) adalah:

a) Menghindari sinar matahari secara langsung serta memilih secara langsung lampu yang dapat memberikan sifat dan penerangan yang tepat.

b) Memilih jenis lampu yang dapat memberikan sifat dan taraf penerangan yang tepat. Misalnya, lampu pijar akan memberikan cahaya yang bersifat setempat, lampu TL/ PL/ Fluorescent akan memberikan cahaya yang merata, lampu sorot akan memberikan cahaya yang terfokos pada objek tertentu.

\section{4) Pewarnaan}

Warna sangat mempengaruhi orang yang bekerja dan membaca di perpustakaan. Warna juga dapat mengoptimalkan konsentrasi dan mempengaruhi jiwa seseorang yang dapat membuat seseorang menjadi nyaman, dan hangat. Warna harus diperhatikan dalam tata ruang perpustakaan untuk mencegah kesan gelap dan silau didalam ruangan penggunaan warna yang tepat pada perpustakaan adalah warna yang menyejukkan agar tidak menyilaukan (Maulani, 2012).

Warna yang kondusif untuk ruang perpustakaan antara lain sebagai berikut :

a) Warna merah menggambarkan panas, warna kegemaran, dan kegiatan bekerja. Warna ini berguna untuk merangsang panca indra dan jiwa agar bermanfaat dalam melaksanakan tugasnya.

b) Warna kuning menggambarkan kehangatan. Warna ini akan merangsang mata dan syaraf dan dapat menimbulkan perasaan gembira.

c) Warna hijau menimbulkan suasana sejuk dan kedamaian. Oleh karena itu, warna ini cocok untuk tempat-tempat ibadah, dan lainnya (Lasa HS, 2005: 164).

Pemilihan warna untuk suatu ruangan perpustakaan sangat erat hubungannya dengan faktor penerangan. Artinya, harus diperhatikan nilai-nilai pemantulannya. Warna dinding sebelah bawah misalnya, harus lebih gelap dari warna dinding sebelah atas, agar tidak terjadi pemantulan dari bagian lain ruang tersebut.

Pemilihan warna yang sesuai untuk ruang dalam akan memberikan kesan suasana yang menyenangkan dan menarik, dapat meningkatkan semangat dan gairah kerja sehingga akan mampu meningkatkan produktivitas kerja, dan juga dapat mengurangi kelelahan (Lasa HS, 2005: 164).

Sementara itu, menurut Purwono dalam Suryanto (2006:355), menyatakan bahwa "Pemilihan warna untuk suatu ruangan agar tampil indah dan nyaman dipadukan dengan perabot, asesoris pendukung tata ruang serta sistem pencahayaan akan menghadirkan suasana ruang yang berbeda-beda. Seperti warna terang (kuning, orange, merah) membuat ruangan terasa meriah, hangat dan akrab.”

Pilihan warna dinding juga dapat mempengaruhi rasa tenang. Karena perpustakaan memerlukan suasana tenang, maka pilihan warna dasar ruangan hendaknya jangan terlalu tajam dan mencolok. Warna netral dan tenang sangat menunjang suasana tenang di perpustakaan (Darmono, 2001: 202).

Dari uraian di atas jelas bahwa warna memiliki pengaruh psikologis bagi manusia. Pemilihan warna yang tepat akan sangat mempengaruhi jiwa seseorang yang dapat membuat 
suasana nyaman, hangat, yang pada gilirannya akan membuat seseorang serta dapat bertahan lebih lama lagi di dalam suatu gedung perpustakaan. Demikian sebaliknya pemilihan warna yang tidak sesuai akan mengakibatkan kejenuhan, rasa bosan, kurang nyaman dan lain sebagainya.

\section{d. Standar Nasional Perpustakaan (SNP 009:2011)}

Standar Nasional Perpustakaan (SNP 009:2011) dimaksudkan untuk menyediakan acuan tentang penyelenggara perpustakaan sekolah menengah atas/Madrasah aliyah baik negeri maupun swasta.

Sebagaimana yang dijelaskan dalam Undang-Undang Nomor 43 Tahun 2007 tentang perpustakaan, khususnya pasal 23 ayat (1) yang menyatakan setiap sekolah menengah atas/madrasah aliyah wajib menyelenggarakan perpustakaan yang memenuhi Standar Nasional Perpustakaan dengan memperhatikan Standar Nasional Pendidikan. Standar Nasional Perpustakaan ini juga ditegaskan dalam pasal 11 yaitu bahwa Standar Nasional Perpustakaan terdiri atas : standar koleksi perpustakaan, standar sarana dan prasarana perpustakaan, standar pelayanan perpustakaan, standar tenaga perpustakaan, standar penyelenggara perpustakaan dan standar pengelolaan perpustakaan (Departmen Pendidikan Nasional RI, 2011: 47).

\section{Perpustakaan Sekolah}

a. Pengertian Perpustakaan Sekolah

Perpustakaan sekolah adalah suatu tempat dimana para siswa memperoleh akses terhadap informasi dan pengetahuan. Perpustakaan merupakan fasilitas pendukung proses pengajaran dan pembelajaran melalui penyediaan bahan pustaka dan pelayanan yang sesuai dengan kurikulum sekolah (Siregar, $2004: 9$ ).

Perpustakaan sekolah adalah perpustakaan yang melayani para siswa, guru, dan karyawan dari suatu sekolah tertentu. Perpustakaan sekolah didirikan untuk menunjang pencapaian tujuan sekolah yaitu pendidikan dan pengajaran seperti digariskan dalam kurikulum sekolah (Rahayuningsih, 2007 : 6).

Pengertian perpustakaan sekolah adalah perpustakaan sekolah yang merupakan salah satu sarana dan fasilitas penyelenggaraan pendidikan, sehingga setiap sekolah semestinya memiliki perpustakaan yang memadai (Sutarno, 2006 : 39).

Dari beberapa pengertian perpustakaan sekolah di atas dapat diketahui bahwa perpustakaan sekolah adalah perpustakaan yang berada di lingkungan sekolah yang sebagai bagian integral dari sekolah, merupakan komponen utama pendidikan di sekolah, yang diharapkan dapat menunjang agar proses pendidikan dapat berlangsung lancar dan berhasil baik.

\section{b. Tujuan Perpustakaan Sekolah}

Tujuan didirikannya perpustakaan sekolah tidak terlepas dari tujuan diselenggarakannya pendidikan sekolah secara keseluruhan, yaitu untuk memberikan bekal kemampuan dasar kepada peserta didik (siswa atau murid), serta mempersiapkan mereka untuk mengikuti pendidikan menengah.

Sejalan dengan hal tersebut di atas, maka tujuan perpustakaan sekolah adalah sebagai berikut:

1) mendorong dan mempercepat proses penguasaan teknik membaca para siswa.

2) membantu menulis kreatif bagi para siswa dengan bimbingan guru dan pustakawan.

3) menumbuhkembangkan minat dan kebiasaan membaca para siswa.

4) menyediakan berbagai macam sumber informasi untuk kepentingan pelaksanaan kurikulum

5) mendorong, menggairahkan, memelihara, dan memberi semangat membaca dan semangat belajar bagi para siswa.

6) memperluas, memperdalam, dan memperkaya pengalaman belajar para siswa dengan membaca buku dan koleksi lain yang mengandung ilmu pengetahuan dan teknologi, yang disediakan oleh perpustakaan.

7) memberikan hiburan sehat untuk mengisi waktu senggang melalui kegiatan membaca, khususnya buku-buku dan sumber bacaan lain yang bersifat kreatif dan ringan, seperti fiksi, cerpen, dan 
lainnya (Yusuf, 2005 : 3).

\section{c. Fungsi Perpustakaan Sekolah}

Menurut Sutarno (2006 : 58) fungsi perpustakaan adalah, "suatu tugas atau jabatan yang harus dilakukan di dalam perpustakaan tersebut. Pada prinsipnya sebuah perpustakaan mempunyai kegiatan utama yaitu menghimpun, memelihara dan memberdayakan semua koleksi bahan pustaka”.

Darmono (2001 : 3) menyatakan bahwa secara umum perpustakaan memiliki beberapa fungsi umum sebagai berikut:

1) fungsi informasi

2) fungsi pendidikan

3) fungsi kebudayaan

4) fungsi rekreasi

5) fungsi penelitian

6) fungsi deposit

Dari beberapa fungsi tersebut maka dapat dilihat bahwa perpustakaan menjadi satu kesatuan integral (terpadu) yang tidak hanya memenuhi minat siswa membaca buku tetapi diharapkan membantu siswa memperluas dan memperdalam pengetahuan.

d. Tugas Perpustakaan sekolah

Perpustakaan sekolah sebagai sumber belajar di sekolah memiliki tugas sebagai berikut :

1) menghimpun atau mengumpulkan, mendayagunakan, memelihara, dan membina secara terus-menerus bahan koleksi atau sumber informasi (bahan pustaka) dalam bentuk apa saja, seperti misalnya buku, majalah, surat kabar, dan jenis koleksi lainnya.

2) mengolah sumber informasi tersebut dengan menggunakan sistem dan cara tertentu, sejak dari bahan-bahan tersebut datang ke perpustakaan sampai kepada siap untuk disajikan atau dilayangkan kepada para penggunanya yakni para siswa dan guru di lingkungan sekolah yang bersangkutan.

3) menyebarluaskan sumber informasi atau bahan-bahan pustaka kepada segenap anggota yang membutuhkannya sesuai dengan kepentingannya yang berbeda satu dengan yang lainnya (Yusuf, 2005 : 7).

Tugas pokok perpustakaan sekolah adalah, "perpustakaan sekolah bertugas menunjang proses pendidikan dengan menyediakan bahan-bahan bacaan yang sesuai dengan kurikulum sekolah dan ilmu pengetahuan tambahan yang lain (Sutarno, 2006 : 40).

Tugas pokok perpustakaan sekolah adalah menghimpun atau mengumpulkan, mengolah, dan menyebarluaskan sumbersumber informasi kepada seluruh pengguna perpustakaan sekolah.

\section{METODE PENELITIAN}

Adapun jenis penelitian yang digunakan adalah deskriptif analitik dengan melakukan analisis data dengan memperkaya informasi, mencari hubungan, membandingkan, menemukan pola atas dasar data aslinya. Hasil analisis data berupa pemaparan mengenai situasi yang diteliti disajikan dalam bentuk uraian naratif. Pada dasarnya pemaparan data dilakukan untuk menjawab pertanyaanpertanyaan mengapa dan bagaimana suatu fenomena terjadi. Peneliti dituntut memahami dan menguasai bidang ilmu yang ditelitinya sehingga dapat memberikan justifikasi mengenai konsep dan makna yang terkandung dalam data (Mania, 2013: 40).

Pendekatan penelitian kualitatif mengkaji perspektif partisipan dengan menggunakan strategi-strategi yang bersifat interaktif, fleksibel dan multi strategi, seperti observasi langsung, observasi partisipatif, wawancara mendalam, dokumen-dokumen teknik-teknik pelengkap seperti foto, rekaman dan lainlain. Hal tersebut karena penelitian kualitatif ditujukan untuk memahami fenomenafenomena social dari sudut pandang partisipan (Sugiyono, 2005).

Di dalam penelitian ini, peneliti berusaha untuk menggali data deskriptif selengkap mungkin yang berupa ucapan hasil wawancara nantinya, ataupun dari data-data tertulis lainnya yang mendukung terhadap kepentingan Peneliti. Pendekatan kualitatif ini digunakan untuk mengungkapkan datadata deskriptif tentang manajemen tata ruang 
di perpustakaan pesantren Madani Alauddin Pao-pao, Gowa.

Penelitian ini berlokasi di perpustakaan pesantren Madani Alauddin Pao-Pao jalan Bontotangnga Pao-pao, kelurahan Paccinongang, kecamatan Somba Opu, kabupaten Gowa. Alasan pemilihan tempat ini karena peneliti menemukan permasalahan tata ruang di perpustakaan tersebut saat sedang melakukan Kuliah Kerja Nyata (KKN) dan alasan ekonomis dekat dari kampus UIN Alauddin dan dari rumah.

Penelitian ini berlangsung selama kurang lebih 1 bulan, dari 4 Januari 2016 hingga 5 Februari 2016 di perpustakaan Pesantren Madani Alauddin Pao-Pao, Gowa.

Informan pada penelitian ini adalah Bapak Drs. H. Andi Achtuh. AB Pasinrengi, M.Pd.I sebagai direktur pesantren, Ibu Herna, S. Ag sebagai penanggung jawab perpustakaan, dan Syahrul Akram sebagai salah satu santri pesantren yang menggunakan layanan perpustakaan.

Tabel 1

Informan Pesantren Madani Alauddin Pao-Pao, Gowa

\begin{tabular}{|l|l|l|}
\hline No. & \multicolumn{1}{|c|}{ Nama lengkap } & \multicolumn{1}{c|}{ Jabatan } \\
\hline 1. & $\begin{array}{c}\text { Drs. H. Andi } \\
\text { Achruh. AB } \\
\text { Pasinrengi, M.Pd.I }\end{array}$ & Direktur Pesantren \\
\hline 2. & Herna, S.Ag & $\begin{array}{l}\text { Penanggung Jawab } \\
\text { Perpustakaan }\end{array}$ \\
\hline 3. & Syahrul Akram & $\begin{array}{l}\text { Santri Pesantren } \\
\text { (Pemustaka) }\end{array}$ \\
\hline
\end{tabular}

Dalam penelitian ini peneliti menggunakan tiga macam teknik dalam pengumpulan data, yaitu observasi (pengamatan), interview (wawancara) dan dokumentasi.

Teknik pengolahan data yang digunakan dalam penelitian ini adalah reduksi data, penyajian data (data display), dan menarik kesimpulan (verifikasi).

Teknik pengujian keabsahan data dalam penelitian ini meliputi uji credibility (validitas internal), uji transferability (validitas eksternal), dependability (reliabilitas) dan uji confirmability (obyektivitas). Dalam hal ini, karena penelitian yang digunakan adalah studi kasus data tunggal, maka peneliti hanya akan menguji validitas dan reliabilitasnya dengan tiga uji yaitu:

1. Uji kredibilitas (validitas internal)

Kredibilitas data atau kepercayaan terhadap data hasil penelitian kualitatif antara lain dilakukan dengan perpanjangan pengamatan, peningkatan ketekunan, triangulasi, analisis kasus negative, dan menggunakan bahan referensi yang cukup.

2. Uji Transferability (validitas eksternal)

3. Uji Dependability (reliabilitas)

(Sugiyono 2007, 121)

\section{Hasil Penelitian dan Pembahasan}

\section{Manajemen tata ruang di perpustakaan pesantren Madani Pao-Pao Alauddin, Gowa}

Terkait dengan latar belakang yang dimiliki penanggung jawab perpustakaan Pesantren Madani Alauddin Pao-pao yaitu Pendidikan Agama Islam, penanggung jawab perpustakaan tidak memiliki dasar pengetahuan yang baik untuk mengelola perpustakaan dengan baik dan benar.

Penanggung jawab perpustakaan, Herna, S.Ag. sudah 2 tahun bekerja sebagai penanggung jawab perpustakaan dan beliau merasa selama bekerja di perpustakaan Pesantren Madani Alauddin Pao-pao sangat ingin berbuat banyak untuk perpustakaan, akan tetapi dia tidak tahu mengembangkan perpustakaan sesuai dengan standar karena tidak berlatar belakang bidang Ilmu Perpustakaan.

Pentingnya manajemen tata ruang menurut penanggung jawab perpustakaan Pesantren Madani Alauddin Pao-pao sangat penting sekali karena segala sesuatu itu apabila dikelola dengan baik pasti hasilnya akan baik pula.

Di sini terlihat betapa pentingnya seorang pengelola perpustakaan memiliki latar belakang pendidikan Ilmu Perpustakaan sehingga dapat dengan mudah mengelola perpustakaan sesuai dengan standar nasional perpustakaan sekolah. 
a. Tujuan tata ruang

Tujuan tata ruang adalah untuk menata ruang perpustakaan itu sehingga tampak lebih baik kemudian bisa menarik simpati bagi siswa ataupun guru-guru untuk mengunjungi perpustakaan.

Tata atau penataan ruang perpustakaan bertujuan untuk memperoleh efektivitas kegiatan dan efisiensi waktu, tenaga dan anggaran, menciptakan lingkungan yang aman suara, nyaman cahaya, nyaman udara dan nyaman warna, meningkatkan kualitas pelayanan, dan meningkatkan kinerja petugas perpustakaan.

b. Sistem tata ruang

Penanggung jawab perpustakaan Pesantren Madani Alauddin Pao-pao tidak mengetahui sistem tata ruang yang digunakan di perpustakaannya. Sistem tata ruang yang digunakan di perpustakaan Pesantren Madani Alauddin Pao-pao adalah sistem tata baur, karena perpustakaan Pesantren madani mengkombinasikan antara penempatan ruang koleksi dan ruang baca dan pemustaka dapat mengambil buku dan mengembalikan buku sendiri di rak perpustakaan Pesantren madani Alauddin Pao-Pao.

c. Ruangan perpustakaan

Perpustakaan Pesantren Madani Alauddin Pao-pao memiliki area koleksi, area baca dan area pelayanan. Namun, perpustakaan belum memiliki ruang tersendiri untuk koleksi, ruang pelayanan, ruang teknis administrasi dan ruang khusus perpustakaan.

Ruangan yang minimal harus dimiliki sebuah perpustakaan adalah ruang koleksi, ruang baca, ruang pelayanan, ruang kerja teknis administrasi, dan ruang khusus. Ini menunjukkan ruangan perpustakaan di Pesantren Madani Alauddin Pao-Pao belum memenuhi standar nasional perpustakaan sekolah.

d. Lingkungan dan kondisi fisik tata ruang perpustakaan
1) Ventilasi udara

Ventilasi udara perpustakaan Pesantren Madani Alauddin Pao-pao memiliki ventilasi udara, akan tetapi ventilasi udaranya itu ditutup dengan karya-karya santri yang berbahan kayu dan dos. Hal tersebut disebabkan karena perpustakaannya menggunakan AC.

2) Pencahayaan

Pencahayaan ruangan perpustakaan Pesantren Madani Alauddin Paopao berasal dari sinar matahari yang menembus ruangan melalui jendelajendela yang ada di perpustakaan. Karena banyaknya jendela yang ada di perpustakaan sehingga lampu ruangan perpustakaan hanya digunakan ketika sore dan malam hari.

e. Masalah yang dihadapi perpustakaan

Masalah yang dihadapi perpustakaan Pesantren Madani Alauddin Pao-pao ialah karena perpustakaan berada satu ruangan dengan laboratorium komputer. Pemustaka merasa sangat terganggu saat berada di perpustakaan dikarenakan kebisingan dari ruang laboratorium komputer.

Pesantren Madani Alauddin Pao-pao kekurangan ruangan sehingga perpustakaan dan laboratorium komputer digabung menjadi satu ruangan. Untuk menjadikan perpustakaan Pesantren Madani Alauddin Pao-pao berjalan sesuai dengan efektif dan efisien, maka Pesantren Madani Alauddin Paopao seharusnya memisahkan antara ruangan perpustakaan dan laboratorium.

\section{Standar Nasional Perpustakaan (SNP 009:2011) Pesantren Madani Pao-Pao Alauddin, Gowa}

a. Gedung perpustakaan

Luas gedung perpustakaan Pesantren Madani Alauddin Pao-pao 6 x 1 meter. Perpustakaan dikatakan memenuhi standar apabila perpustakaan tersebut menyediakan gedung atau ruang yang cukup untuk koleksi, staf dan pemustakanya dengan ketentuan bila 3 sampai 6 rombongan belajar seluas $112 \mathrm{M}^{2}$ $\mathrm{M}^{2}$, 7 sampai 12 rombongan belajar seluas $168 \mathrm{M}^{2} \mathrm{M}^{2}$, 13 sampai 18 rombongan belajar 
seluas $224 \mathrm{M}^{2} \mathrm{M}^{2}$, 19 sampai 27 rombongan belajar seluas $280 \mathrm{M}^{2} \mathrm{M}^{2}$. Lebar minimal perpustakaan adalah $5 \mathrm{M}^{2} \mathrm{M}^{2}$.

Berdasarkan pernyataan di atas perpustakaan Pesantren Madani Alauddin Pao-pao belum memenuhi Standar Nasional Perpustakaan.

b. Area perpustakaan

Perpustakaan Pesantren Madani Alauddin Pao-pao memiliki area koleksi, area baca dan area kerja namun belum memiliki area multimedia. Standar Nasional Perpustakaan (SNP 009:2011) mengenai area perpustakaan:

Gedung/ ruang perpustakaan sekurangkurangnya meliputi; area koleksi, area baca, area kerja, dan area multimedia

Perpustakaan Pesantren Madani Alauddin Pao-pao juga belum memenuhi Standar Nasional Perpustakaan karena belum memiliki area multimedia.

\section{c. Sarana perpustakaan}

Sarana yang dimiliki perpustakaan Pesantren Madani Alauddin Pao-pao meliputi : rak buku 7 buah, rak majalah 1 buah, rak surat kabar 1 buah, meja baca 2 buah, kursi baca tidak ada, kursi kerja 2 buah, lemari catalog tidak ada, lemari tidak ada, papan pengumuman 1 buah, meja sirkulasi 1 buah, majalah dinding tidak ada, rak buku referensi 1 buah, perangkat komputer/administrasi 1 buah, perangkat internet tidak ada, fasilitas OPAC 1 buah, Tv tidak ada, pemutar DVD tidak ada, tempat sampah 1 buah, jam dinding 1 buah.

Dalam memenuhi Standar Nasional Perpustakaan, perpustakaan menyediakan sarana perpustakaan sekurang-kurangnya meliputi; rak buku 15 buah, rak majalah 1 buah, rak surat kabar 1 buah, meja baca 15 buah, kursi baca 30 buah, kursi kerja 3 buah, lemari katalog 1 buah, lemari 2 buah, papan pengumuman 1 buah, meja sirkulasi 1 buah, majalah dinding 1 buah, rak buku referensi 2 buah, perangkat komputer/ administrasi 1 buah, perangkat internet 2 buah, fasilitas OPAC 1 buah, Tv 1 buah, pemutar DVD 1 buah, tempat sampah 3 buah, jam dinding 2 buah.
Sarana perpustakaan Pesantren Madani Alauddin Pao-pao ada yang sudah memenuhi Standar Nasional Perpustakaan dan ada juga yang belum memenuhi Standar Nasional Perpustakaan.

\section{d. Lokasi perpustakaan}

Lokasi perpustakaan Pesantren Madani Alauddin Pao-pao berada di pusat kegiatan pembelajaran yang mudah dilihat serta mudah dijangkau oleh peserta didik, pendidik dan tenaga kependidikan.

Dalam memenuhi Standar Nasional, lokasi perpustakaan juga perlu diperhatikan yakni lokasi perpustakaan harus berada di pusat kegiatan pembelajaran yang mudah dilihat serta mudah dijangkau oleh peserta didik, pendidik dan tenaga kependidikan.

Lokasi perpustakaan Pesantren Madani Alauddin Pao-pao sudah memenuhi Standar Nasional Perpustakaan hal ini dilihat karena lokasi perpustakaan Pesantren Madani Alauddin Pao-pao sangat strategis.

\section{E. Kesimpulan}

Berdasarkan hasil penelitian dan pembahasan manajemen tata ruang perpustakaan Pesantren Madani Alauddin Paopao dan Standar Nasional Perpustakaan (SNP 009:2011) tentang ruangan perpustakaan, maka dapat ditarik kesimpulan yaitu :

1. Pesantren Madani Alauddin Pao-pao masih dalam tahap pembangunan atau perkembangansehinggaruangannyabelum terlalu banyak dan untuk memanfaatkan itu perpustakaan dan laboratorium komputer digabung menjadi satu ruangan dampaknya kembali ke pemustaka yang tidak dapat menikmati layanan perpustakaan dengan baik akibatnya pemustaka tidak dapat konsentrasi atau merasa sangat terganggu apabila ia membaca dan ada juga santri yang belajar di laboratorium, sistem tata ruang yang digunakan perpustakaan Pesantren Madani Alauddin Pao-pao adalah sistem tata baur yang dimana penempatan koleksi yang dicampur dengan ruang baca agar pemustaka lebih mudah mengambil dan mengembalikan sendiri buku. Perpusatakaan Pesantren Madani Alauddin Pao-pao 2 buah meja 
akan tetapi tidak memilki kursi baca sebab perpustakaan Pesantren Madani Alauddin Pao-pao menggunakan sistem lesehan atau duduk dilantai yang beralaskan tikar atau karpet. Perpustakaaan Pesantren Madani Alauddin Pao-pao memilki ventilasi udara akan tetapi tertutupi dengan karya santri-santri yang berbahan kayu dan dos sebab perpustakaannya menggunakan AC. Sistem pencahayaan di Pesantren Madani Alauddin Pao-pao dari matahari langsung yang menembus jendela-jendela perpustakaan.

2. Ruangan perpustakaan Pesantren Madani Alauddin Pao-pao terkait dengan kebutuhan pemustaka sudah terpenuhi untuk bagian area perpustakaan dan lokasi perpustakaan sebagaimana yang ada dalam Standar Nasional Perpustakaan (SNP 009:20011) . Hanya saja gedung / ruang perpustakaan dan sarana perpustakaan Pesantren Madani Alauddin Pao-pao yang belum memenuhi Standar Nasional Perpustakaa (SNP 009:20011) sebagaimana mestinya. Tapi, pihak sekolah maupun pihak perpustakaan akan berusaha dalam memenuhi sarana tersebut.

Mengacu pada hasil kesimpulan yang dikemukakan di atas, maka untuk mengembangkan, memperbaiki dan meningkatkan pelaksanaan manajemen tata ruang dan SNP 009:2011, peneliti memberikan saran ataupun kritik sebagai berikut :

1. Agar perpustakaan selain dapat menjalankan fungsinya dan tugasnya dengan baik maka perpustakaan harus memilki ruangan tersendiri dan tidak digabung lagi dengan laboratorium komputer.

2. Penerapan Penerapan SNP 009:2011 perlu diwujudkan oelh setiap perpustakaan khususnya perpustakaan sekolah menengah atas/ madrasah aliyah, agar suatu perpustakaan selain dapat mejalankan dapat menjalankan fungsinya dan tugasnya dengan baik akan tercipta pula suatu perpustakaan yang ideal yang menunjang segala aspek kebutuhan pemustaka utamanya dalam hal pengetahuan informasi. Berdasarkan penelitian yang dilakukan oleh peneliti, perpustakaan Pesantren Madani Alauddin Pao-pao belum bisa dikatakan memenuhi Standar Nasional Perpustakaan sebab masih banyak sarana perpustakaan yang belum terpenuhi.

Dari beberapa criteria yang ada dalam SNP 009:2011 kiranya pihak perpustakaan perlu menyesuaikan dan memenuhi criteria standar lainnya yang belum memenuhi criteria SNP 009:2011 khususnya sarana perpustakaan.

\section{Daftar Pustaka}

Ahmad, Riska. Pengolahan Program BK. Padang: Universitas Negeri Padang, 2002.

Anugrah, Dexa. "Penataan Ruangan di Perpustakaan Umum Kota Solok". Jurnal Informasi Perpustakaan dan Kearsipan, 1. 2 (2013): 2

Arikunto, Suharsimi. Prosedur Penelitian suatu Pendekatan Praktik. Jakarta: Reneka Cipta. Departemen Pendidikan Nasional RI, 2006.

Bafadal, Ibrahim. Pengelolaan Perpustakaan Sekolah. Jakarta: Bumi Askara, 2009.

Damopolli, Muljono. Pedoman Penelitian Karya Tulis Ilmiah: Makalah, Skripsi, Tesis, Disertasi dan Laporan Penelitian. Makassar: Alauddin Press, 2014.

Darmono. Manajemen dan Tata Kerja Perpustakaan Sekolah. Jakarta: Grasindo,

2001.

Departmen Pendidikan Nasional RI. Perpustakaan Perguruan Tinggi: Buku Pedoman. Jakarta: Departemen Pendidikan Nasional RI, 2004.

-. Pedoman Umum Penyelenggara Perpustakaan Sekolah. Jakarta: Perpustakaan Nasional, 2005.

Draft, Richard L. Manajemen. Jakarta: Erlangga, 2002.

Fahmi, Yusri. "Desain Gedung Perpustakaan Perguruan Tinggi”. Jurnal Khizanah Al-Hikmah, 1.2 (2013): 5

Lasa HS. Membina Perpustakaan Madrasah \& Sekolah Islam. Yogyakarta: Adicita Karya Nusa, 2005.

-. Manajemen Perpustakaan Sekolah. Yogyakarta: Pinus Book Publisher, 2007.

Iskandar. "Pengaruh Tata Ruang Perpustakaan Terhadap Peningkatan Kunjungan Pemustaka di UPT Perpustakaan Pusat Universitas Islam Negeri Alauddin Makassar”. Skripsi. Makassar: Fakultas Adab dan Humaniora 
UIN Alauddin, 2013.

Mania, Sitti. Metodologi Penelitian Pendidikan dan Sosial. Makassar: Alauddin University Press, 2013.

Mathar, Muh. Quraisy. Manajemen dan Organisasi Perpustakaan. Makassar: Alauddin University Press, 2012.

Maulani, Irfan Fauzi. "Pengaruh Tata Ruang terhadap Motivasi Kerja”. E-journal Mahasiswa Universitas Padjadjaran, 1.1 (2012): 3-4

Moleong, Lexy J. Metode Penelitian Kualitatif. Edisi Revisi; Bandung: PT Remaja Rosdakarya, 2011.

Permata, Sari. Rumah Muslim yang di Takuti Setan : Kunci Dahsyat Rumahku Adalah Surgaku. Jakarta: Kunci Iman,

Prastowo, Andi. Manajemen Perpustakaan Sekolah Profesional. Yogyakarta: Diva press, 2012.

Purwanti, Sri. Tata Ruang, Perabot dan Perlengkapan Perpustakaan Sekolah. Surabaya: Mimbar Pustaka, 2007.

Pustaka Phoenix. Kamus Besar Bahasa Indonesia. Jakarta Selatan: Kamus Besar Bahasa Indonesia, 2013.

Rahayuningsih. Pengelolaan Perpustakaan. Yogyakarta: Graha Ilmu, 2007.

Rodin, R. "Penerapan Knowladge Management di Perpustakaan: Studi Kasus di Perpustakaan STAIN Curup”. Khizanah al-Hikma, 1. 2 ,
(2013): 40

Sedarmayanti. Dasar-dasar Pengetahuan tentang: Manajemen Perkantoran. Bandung: Mandar Maju, 2001.

Siregar, A. Ridwan. Perpustakaan: Energi Pembangunan Bangsa. Medan: USU Press, 2004.

Sugiyono. Metode Penelitian Kuantitatif, Kualitatif dan R\&D. Bandung: Alfabeta, 2010.

-... Memahami Penelitian Kualitatif. Bandung: Alfabeta, 2005.

-.-. Metode Penelitian Kuantitatif, Kualitatif, Dan R\&D. Bandung: Alfabeta, 2014.

Sulistiyo-Basuki. Pengantar dokumentasi. Bandung: Rekayasa Sains, 2004.

Sutarno NS. Manajemen Perpustakaan: Suatu Pendekatan Praktik. Jakarta: Sagung Seto, 2006.

Suwarno, Wiji. Perpustakaan dan Buku. Jogjakarta: AR-Ruzz Media, 2011.

Undang -Undang RI Nomor 43 Tahun 2007 Tentang Perpustakaan. Jakarta: Tamita Utama, 2009. 